\title{
Governance and Performance: Publicly Listed Companies in Malaysia
}

\author{
Cyril H. Ponnu \\ University of Malaya, Malaysia \\ Sarimah Ramthandin \\ Securities Commission Malaysia, Malaysia
}

\begin{abstract}
This paper investigates the relationship between corporate governance practice (as indicated by corporate governance disclosure) and company's financial performance. Certain corporate structures and practices were examined to determine if they have any effect on company's performance. Corporate governance practices were assessed based on the level of disclosure made in the companies' annual reports. For financial performance, stock price performance and return on equity (ROE) were used as proxies. Results show that there is a positive relationship between the corporate governance practices and company performance. Findings from this research could be used by regulators, investors, corporations and others who contend that good corporate governance is important for increasing firm's performance and investor confidence.
\end{abstract}

\section{Keywords}

Corporate governance, company performance.

\section{Introduction}

An important lesson learned from the 1997/98 Asian financial crisis was that poor corporate governance could lead to recklessness and excesses, resulting in severe financial difficulties. The crisis significantly changed the financial and economic landscape of the affected countries in the Asian region including Malaysia. To bring about better corporate governance, crisis-hit countries resorted to stricter securities regulations, reforms in company law, stringent accounting practices and auditing standards, tighter bankruptcy law and stronger judicial enforcement.

A substantial literature has documented general links between corporate governance practices and company performance. The literature suggests that both market and non-market mechanisms could be used to promote the alignment of interests of managers and stakeholders. However, the evidence is mixed. Research on the relationship between corporate governance practices and firms' performance has failed to establish a concrete link between the two variables.

Thus, this study seeks to investigate if there is a relationship between corporate governance practices

Copyright $(0) 2008$ Victoria University. This document has and companies' financial performance.

been published as part of the Journal of Business Systems, Governance and Ethics in both online and print formats. Educational and non-profit institutions are granted a nonexclusive licence to utilise this document in whole or in part for personal or classroom use without fee, provided that correct attribution and citation are made and this copyright statement is reproduced. Any other usage is prohibited without the express permission of the 


\section{Literature Review}

\section{Corporate governance and firm's performance}

Generally, firms with relatively poor governance are relatively less profitable, less valuable and pay out less to their shareholders (Brown and Caylor, 2004).

In contrast, some studies showed that there is a negative relationship between corporate governance practise and firm's performance. The fact that better-governed firms achieve higher valuations does not necessarily imply that governance quality is fully reflected in firm value. In fact, Gompers et al. (2003) show that firms with higher investor rights outperform firms with lower investor rights by $0.71 \%$ per month. Drobetz et al. (2004) calculate that the difference in monthly returns is $1.37 \%$ for German firms.

These results suggest that corporate governance ratings contain information not entirely impounded in stock prices. However, Bauer et al. (2004) find that governance-based portfolios yield negligible excess returns in the UK and EMU markets, which suggests that any difference in corporate governance might already be reflected in current stock prices.

\section{Selected corporate governance practices and financial performance}

Various studies have been done on the relationship between specific corporate governance attributes and firm's performance.

Rechner and Dalton (1991) examined the relation between CEO duality and organizational performance. Their study supports agency theory expectations about inferior shareholder returns from CEO duality. Rechner and Dalton (1989) also examined the effect of CEO duality on risk-adjusted shareholder returns using stock market data for the same sample and period. They found no significant difference between structures.

Donaldson and Davis (1991) examined the effects of CEO duality on shareholder returns, and recorded exactly the opposite result to that of Rechner and Dalton (1991). Their results show that the average ROE of the board with chairs independent of the CEO was $11.5 \%$, less than the average ROE of those companies with CEO duality at $14.8 \%$. The difference was statistically significant, i.e., dual CEO structures outperform independent chair structures.

Byrd and Hickman (1992) report that tender offer bidders with majority-independent boards earn roughly zero stock price returns on average, while bidders without such boards suffer statistically significant losses of $1.8 \%$ on average. You et al. (1986) also report a significant negative correlation between proportion of inside directors and bidder stock price returns. This suggests that independent directors may help restrain the tendencies of CEOs to build larger empires, even if this means overpaying to buy another company.

Denis and Sarin (1997) report that firms that substantially increased the proportion of independent directors had above-average stock price returns in the previous year. In a study to assess investor reaction to the appointment of additional directors, Rosenstein and Wyatt (1990) found that stock prices increase by about $0.2 \%$ on average, when companies appoint additional outside directors. This increase was statistically significant, but economically small.

Whereas Bhagat and Black (2002) find no relationship between the proportion of independent directors and various indicators of firm performance, Rosenstein and Wyatt (1990) observe a positive market reaction to the appointment of independent directors. Perry and Shivdasani (2005) explain that firms with a majority of outside directors are more likely to restructure following performance declines, and more determined in doing so.

As regards the relationship between ownership concentration and firm performance, empirical results in the USA are inconclusive. Demsetz and Lehn (1985) found no significant correlation between ownership concentration and profit rates for 511 large corporations. Morck et al. (1988) reported a 
piecewise linear relationship of Tobin's Q with board member ownership for 371 Fortune 500 firms, and also found evidence of an inverted U-shaped relationship between the degree of ownership concentration and profitability.

Stulz (1988) demonstrates that higher managerial ownership can insulate managers from external takeovers, and by allowing managers to block takeover bids, can lower firm value. Using US data, Morck et al. (1988), McConnell and Servaes (1990; 1995), Hermalin and Weisbach (1991), and Holderness et al. (1999) all find firm value to rise with low levels of managerial ownership and to fall with higher levels of managerial ownership.

Several empirical studies in accounting have focused on the voluntary formation of audit committees to identify factors affecting an entity's decision to create an audit committee directly responsible for overseeing the financial reporting process (Pincus et al., 1989). Collectively, these studies suggest that larger companies, who are audited by the Big Five and who have bigger boards with greater representation of outside directors, are among the companies more likely to voluntarily form an audit committee.

Several studies document that the presence of an audit committee is associated with fewer incidences of financial reporting problems. For example, McMullen (1996) finds that entities with more reliable financial reporting, such as those with absence of material errors, irregularities and illegal acts, are significantly more likely to have audit committees.

DeChow et al. (1996) show that firms subject to Securities Exchange Commission, USA (SEC) enforcement actions are less likely to have standing audit committees. More recent descriptive research shows that $25 \%$ of the companies subject to SEC enforcement actions do not have audit committees in place (COSO, 1999). Carcello and Neal (1999) find that the likelihood a company in financial distress will receive a going concern modified auditor's report is lower when the percentage of inside or grey directors on the audit committee is higher.

\section{Research Hypotheses}

This study is intended to examine the link between corporate governance practice and firm's performance. It should be noted that there are many factors that affect a firm's performance. It is either internally driven or externally controlled. However, in examining the relationship between corporate governance practice and firm's performance, it is assumed that all factors contributing to firm's performance have same level of influence on the selected sample. Thus, the following hypotheses have been developed:

H1: There is a positive relationship between corporate governance practice and stock price performance

This hypothesis was developed on the basis that investors are willing to put in their money in a well governed company; ultimately will boost investors' sentiments of the stock from bearish to bullish.

$\mathrm{H}_{2}$ : There is a positive relationship between corporate governance practice and return on equity.

This hypothesis was developed on the basis that a well governed company always try to maximize shareholder's return which would translate into better bottom line as denoted by return on equity.

\section{Research Method}

\section{Corporate governance rating}

Generally, corporate governance rating is meant to indicate the relative level to which an organization accepts and follows the codes and guidelines of corporate governance practices. In this research, the rating system constructed by MICG-Uitm-RAM and Biz Aid Technologies Sdn Bhd was employed. The 
reason for this decision was the rating system is customized to local business corporation environment and addresses the governance issues that are relevant to the Malaysian scenario.

\section{MICG-Uitm-RAM-Biz Aid Technologies Corporate Governance Rating}

In developing the corporate governance rating system, the consortium has prepared a Corporate Governance Score Checklist that draws upon the requirement made in Malaysian Code of Corporate Governance, Bursa Malaysia Listing Requirements, The Cadbury Report, the Organisation for Economic Cooperation and Development (OECD) Corporate Governance Principles as well as other prevalent codes, guidelines and research findings.

According to the consortium, the set of corporate governance attributes determined by them does not only representative of Malaysia's corporate reality but also simultaneously emphasis the real life practicability and world-class quality goals. In addition, the proposed corporate governance reporting framework will also be universally applicable to the international markets and acceptable by investment institutions and other relevant bodies.

The figure below depicts the eight principal corporate governance attributes that were used as the Corporate Governance Score Checklist main headings.

Figure 1: Specific Attributes in the Corporate Governance Index

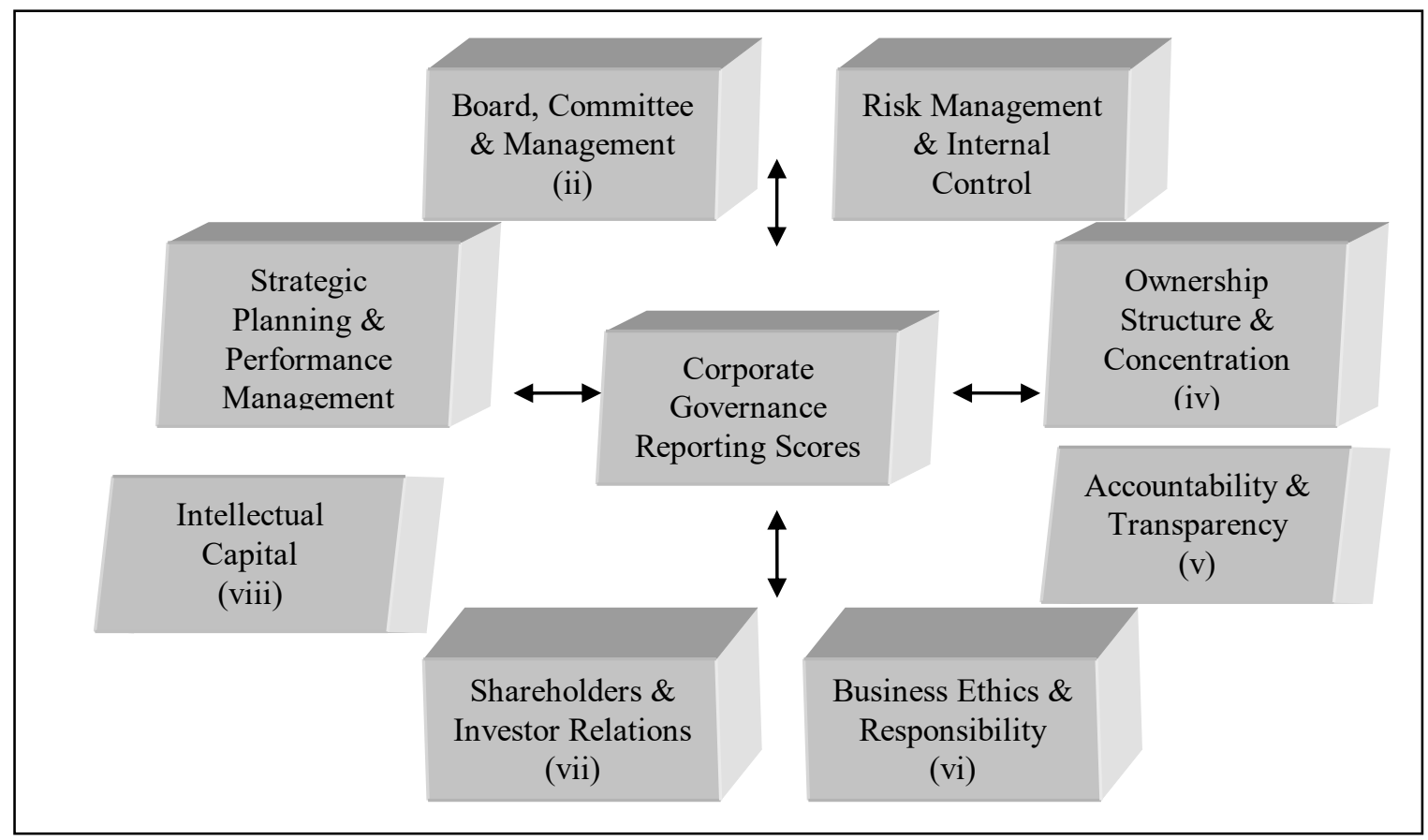

Source: Corporate Governance Reporting of Top 100 Public Listed Companies in Malaysia

The attributes are measured through a 5-point Likert Scale, and the maximum score that could be obtained by each company is 375 points.

The consortium has also assigned weights to each principal attributes based on the relative importance of the attribute. Basically, a higher weighting has been given to those requirements specifically spelt out by Malaysian Code of Corporate Governance. The weighting has been further gauged against other corporate governance studies world wide. Items that are not particularly deliberated by the Code but emphasized in major studies world wide have been assigned slightly lower weighting. A percentage was then computed with $100 \%$ being the perfect score.

Below is the detail of the raw score and the weighting applied for each attribute.

Table 1: Raw Score \& Weighting of Specific Corporate Governance Attributes

No. Corporate Governance Attributes

Total Raw

Weighting 


$\begin{array}{llll} & & \text { Score } & \mathbf{( \% )} \\ \text { 1. } & \text { Strategic Planning \& Performance Management } & 30 & 5 \\ \text { 2. } & \text { Board, Committee \& Management } & 85 & 15 \\ \text { 3. } & \text { Risk Management \& Internal Control } & 40 & 15 \\ \text { 4. } & \text { Ownership Structure \& Concentration } & 35 & 15 \\ \text { 5. } & \text { Accountability \& Transparency } & 85 & 20 \\ \text { 6. } & \text { Shareholders \& Investor Relations } & 40 & 15 \\ \text { 7. } & \text { Business Ethics \& Responsibility } & 30 & 10 \\ \text { 8. } & \text { Intellectual Capital } & 30 & 5 \\ & \text { Total } & 375 & 100\end{array}$

Mathematically, the weighted corporate governance score could be expressed as:

TCGSi $=\sum$ RCGS $\mathrm{x} w$

where,

RCGS $=$ ratio of score assigned to each category to total score of each category.

$\mathrm{W}=$ weighting assigned for each category in the form of percentage.

\section{Corporate governance disclosure}

This research will assess the level of corporate governance disclosure by carefully studying the annual reports of the selected companies. Scores will then be assigned based on the metrics outlined above. This is to measure the level of corporate governance disclosure among the listed companies. Descriptive analysis will be applied to analyse the extent of corporate governance disclosure.

\section{Sample design}

The sample companies are drawn from the 100 composite index component companies on Bursa Malaysia. The selection is based on the market capitalization of these companies as at 31 December 2006. The rationale of this selection lies on the fact that these companies make up the composite index, which is the barometer of stock market performance. The companies are also expected to practice a high level of corporate governance disclosure in their annual reports. In addition, these companies are most likely to attract the institutional investors' interest, be it local or international.

\section{Data collection procedure}

This research utilizes secondary data, information available in the companies' annual reports. Annual report was chosen due to the fact that it was deemed to be the common communication tool employed by company to disclose relevant information to the shareholders. The level of disclosure made in the annual report is essential to the functioning of corporate governance (Keasey et.al, 1999), enabling management to communicate company's performance and practice to shareholders (Healy and Palepu, 2001).

The Listing Requirements of Bursa Malaysia requires all listed companies to disclose certain information pertaining to corporate governance practice in their annual reports. Hence, this research chose to extract the relevant information from the latest annual reports (2005 and 2006) of the selected companies. The Return on Equity (ROE) and stock prices of the selected companies was obtained from The Star online (www.thestar.com my), research reports and annual reports.

\section{Statistical analysis}

This research employs the SPSS statistical software for analyzing the data. A descriptive analysis was employed in determining the extent of corporate governance practices disclosure among the selected 
companies, based on the scores of each corporate governance attribute as well as the total score of the attributes.

In examining the link between corporate governance and firm's performance, correlation analysis was applied.

Table 2: Variables Used For Hypotheses Explanation

\begin{tabular}{|c|c|c|}
\hline Variables & Notation & Definition \\
\hline $\begin{array}{l}\text { Total CG Score } \\
\text { (Independent) }\end{array}$ & TCGS & $\begin{array}{l}\text { Conversion of total of each category's score into } \\
\text { total raw score }\end{array}$ \\
\hline $\begin{array}{l}\text { Total weighted CG } \\
\text { score }\end{array}$ & TWCGS & $\begin{array}{l}\text { Conversion total of each category's score into total } \\
\text { weighted score }\end{array}$ \\
\hline $\begin{array}{l}\text { Return on equity } \\
\text { (Dependent) }\end{array}$ & ROE & $\begin{array}{l}\text { The return of equity of the selected companies as } \\
\text { at } 31 \text { December, } 2006 \text {. }\end{array}$ \\
\hline Stock Prices & SP & $\begin{array}{l}\text { Stock price ( } 2 \text { January to } 31 \text { December changes } \\
\text { i.e. within one year period of holding) }\end{array}$ \\
\hline
\end{tabular}

Where TCGS is total raw score corporate governance score.

\section{Data Analysis and Results}

\section{Descriptive analysis}

A descriptive analysis was done to describe the level of corporate governance practice of the selected sample. The analysis of total corporate governance scores (raw and weighted) and specific corporate governance attributes are discussed in the ensuing parts.

\section{Overall Disclosure of Corporate Governance Practice}

The disclosure level of corporate governance practice is summarized in Table 3.

Table 3: Disclosure Level of Corporate Governance Practice

$\begin{array}{lllll}\text { Measures } & \text { Min } & \text { Max } & \text { Mean } & \text { Median } \\ \text { Value (Raw CG Score) } & 101 / 375 & 225 / 375 & 172.09 & 172.50 \\ \text { Percentage (Weighted score) } & 40.25 \% & 66 \% & 51.15 \% & 52.07 \%\end{array}$

Figure 2: Raw Corporate Governance Score

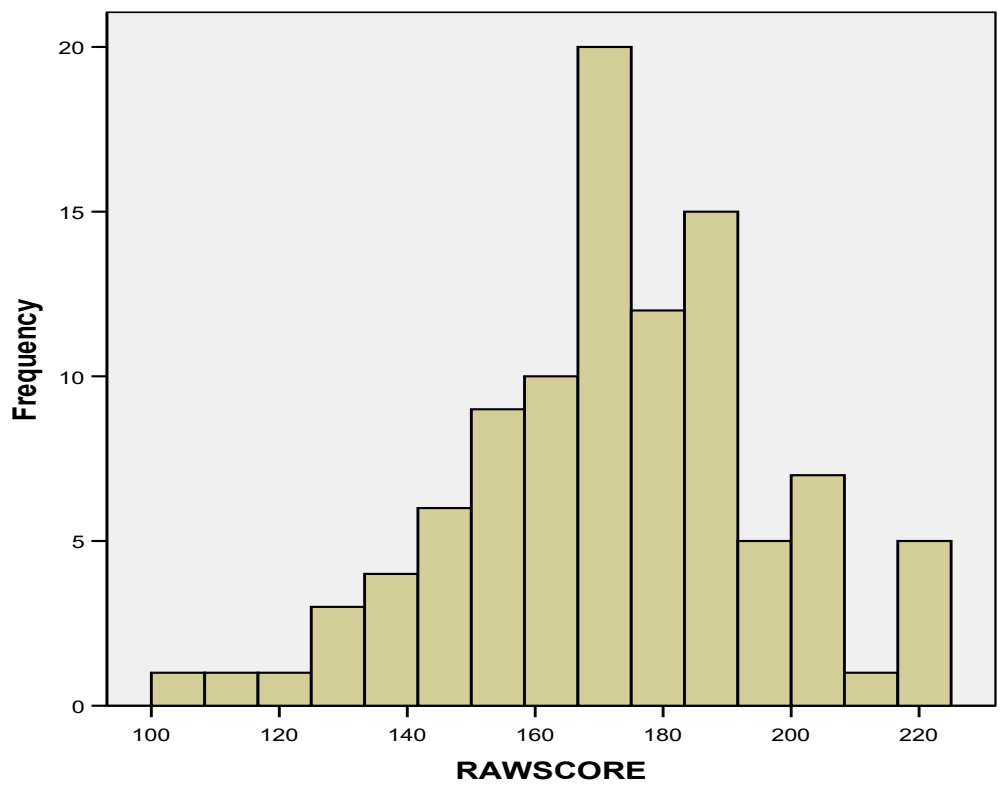

Mean $=172.09$
Std. Dev. $=23.981$ 
Figure 3: Weighted Corporate Governance Score

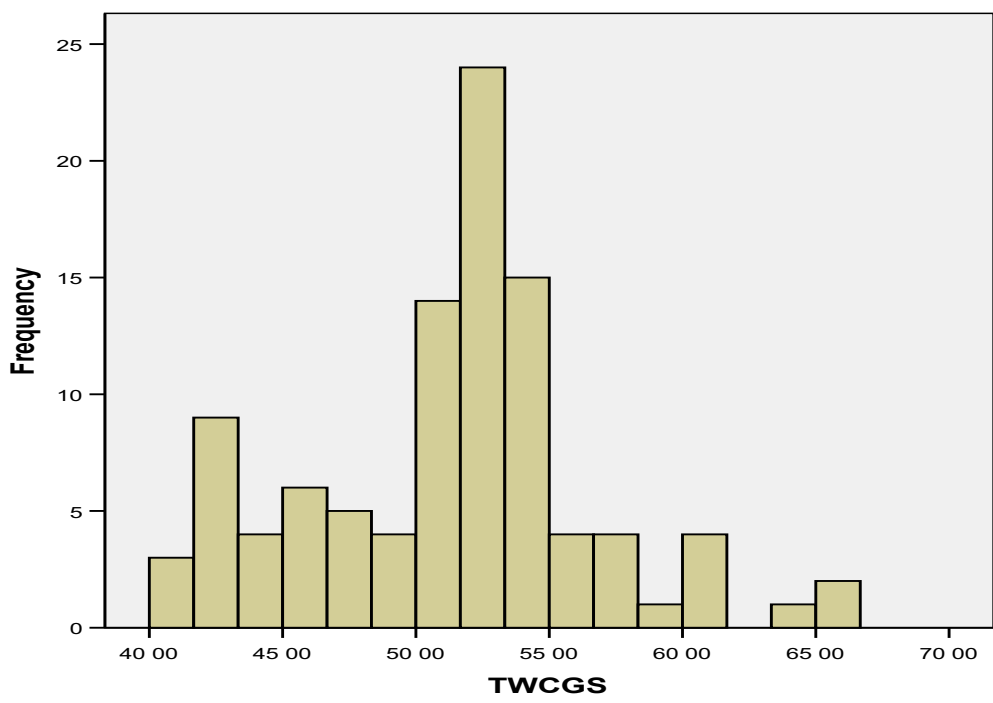

$\begin{aligned} & \text { Mean }=51.1555 \\ & \text { Std. Dev. }=5.40515 \\ & N\end{aligned}$

Based on Figures 2 and 3 above, it can be concluded that there is not much difference in the level of corporate governance disclosure among the selected companies. In fact, the majority of the companies have about similar scores in terms level of disclosure, which falls within the band of 160 to 180 score and the weighted score of 50 to $55 \%$. This shows companies somehow have developed among themselves an acceptable level of corporate governance disclosure. It was also noted that most companies employed PricewaterhouseCoopers or Ernst \& Young as their external auditors, which explains the similar format or corporate governance reporting.

\section{Analysis of specific corporate governance attributes}

The followings are the results on the level of disclosure among the specific corporate governance attributes:

\section{Strategic Planning and Performance Management}

This attribute examines the strategic formulation and implementation of the company's vision, mission and its goals. The measurement criteria of this attribute are specified in Table 4.

Table 4: Measurement Criteria for Strategic Planning and Performance Management Attribute

No. Measurement Criteria

1. State the company's vision, mission and organizational goals

2. Explains on goal congruence

3. Identify core competencies

4. Conduct interim review of company's vision and goals

5. Identifying company's KPI

6. Distinguish each type of company's business

\section{Score}

M n mum: 6/30

Max mum: $24 / 30$

Mean: 13.26

Med an:13

Standard dev at on: 4.06 
Figure 4: Disclosure of Strategic Planning and Performance Management

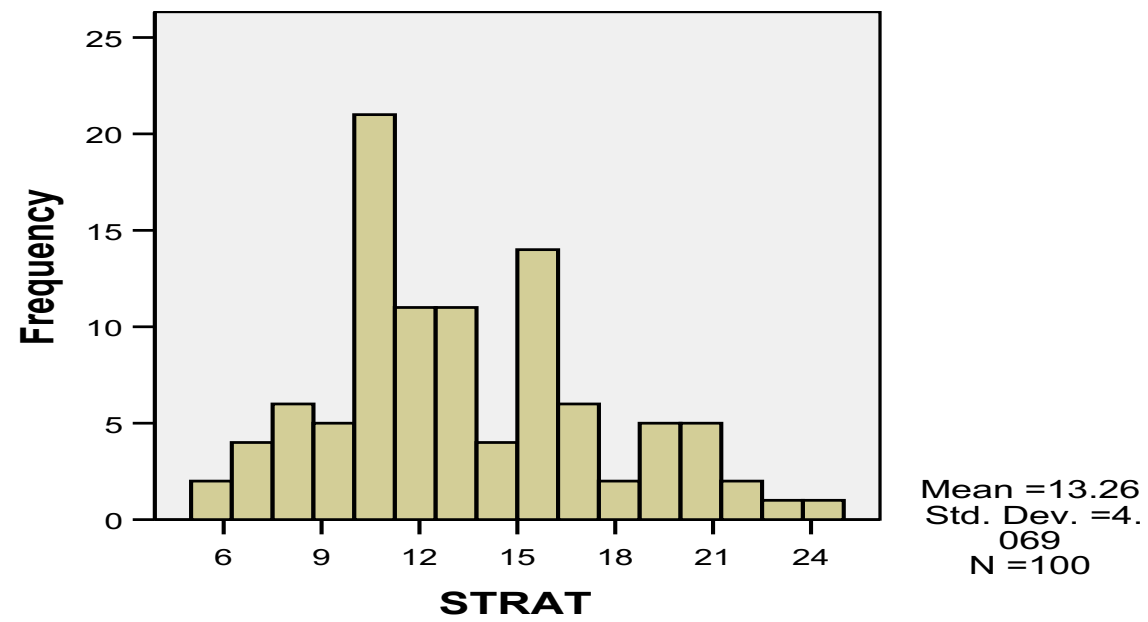

From the above result, it is noticed that many companies did not disclose much information about their strategic planning and performance management. Most companies disclosed their mission and vision only on the surface without much explanation on how to achieve them. Among the companies that made quite an extensive disclosure on their strategic planning and performance management was AMMB Holdings, Public Bank, Maxis and Astro. In terms of business KPIs, most companies tend to disclose only financial ratios, share information and profitability measures. Target forecasts of these indicators were not mentioned, probably the board does not want to be accountable for target goals that could not be achieved.

\section{Board, Committee and Management}

The Board is collectively responsible for the success of the company by directing and supervising its affairs. The board, committee and its management are the governance drivers that must steer the company towards achieving its goals. Table 5 lists out the attribute that measures the effectiveness and efficiency of the Board, Committee and Management.

Table 5: Disclosure of Board, Committee and Management

No. Measurement Criteria

1. Disclosure of historical development and significant events taking place within the financial year

2. Disclosure on major decisions made by the Board, Committee and Management

3. Disclosure of appointments and re-appointments policies of the Board of Directors and top management

4. Disclosure on Board size and other pertinent characteristics

5. Training policies

6. Disclosure of the Board and management jobs descriptions

7. Disclosure on the communication policies

8. Disclosure of significant issues that were raised during AGMs/EGMs

9. Notes on the various established committees

10. Evaluation of the Board Members

Score

M n mum: $54 / 85$

Max mum: 75/85

Mean: 64.07

Med an:64

Standard dev at on: 5.14 
Figure 5: Disclosure of Board, Committee and Management

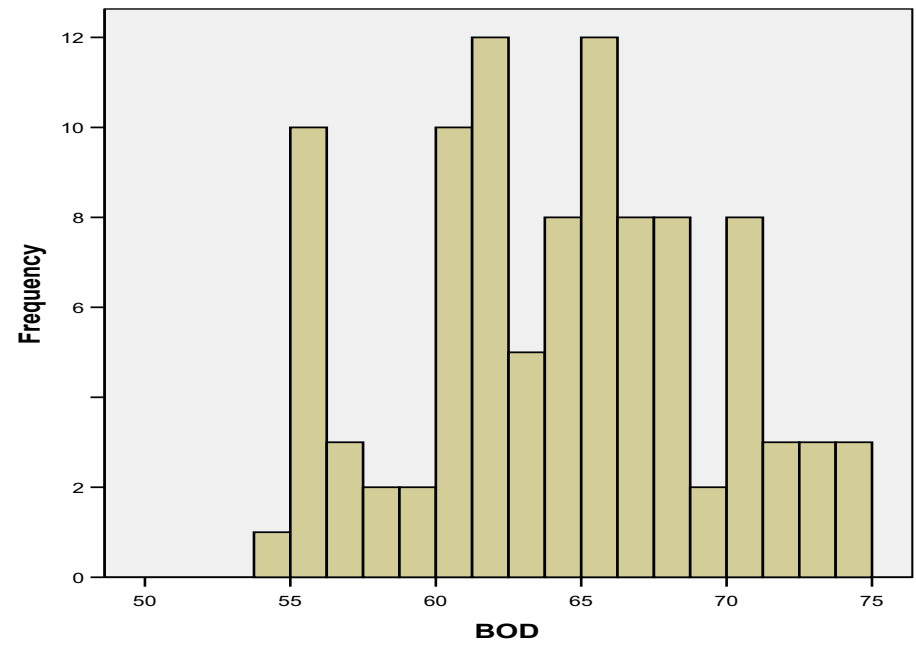

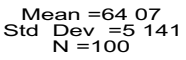

Based on the results, it can be noted that on average companies scored between $60-68$ points on the disclosure of this attribute. This may be due to the mandatory disclosure required by the Listing Requirements of Bursa Malaysia in this aspect. Hence, there is high level of compliance. Those companies that scored high in this area are also award winners on corporate governance compliance. For example, amongst others, Maybank, IJM , Public Bank, Genting Berhad and Tanjong Plc.

\section{Risk Management and Internal Control}

Most codes of corporate governance emphasize the need for a sound system of internal control to be maintained by a company in managing and controlling its principal risks. This attribute measures risk management attitude of the company and steps taken to control and manage the risks. Table 6 explains the measurement criteria for this attribute.

Table 6: Disclosure of Risk Management and Internal Control
No. Measurement Criteria
1. Disclosure of risk management framework
2. Identification of business risks
3. Disclosure on internal control system and procedures
4. Disclosure of contingency planning
5. How the Board inculcate the risk management culture
6. Audit compliance
7. Audit adequacy
8. Internal audit programme

Score

M n mum: $12 / 40$

Max mum: $37 / 40$

Mean: 25.49

Med an:26

Standard dev at on: 5.11 
Figure 6: Disclosure of Risk Management and Internal Control

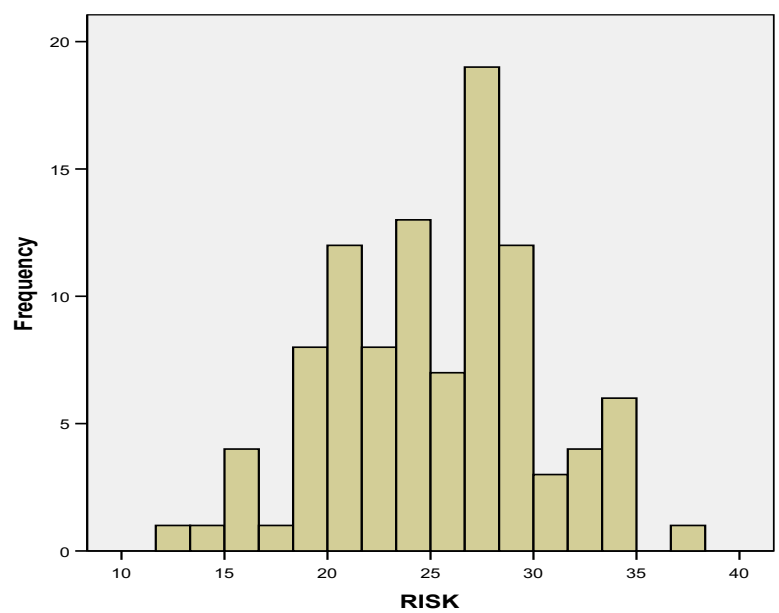

Mean 25
Std Dev
N 100

There has been a slight improvement in terms of disclosure of risk management and internal control. Previous studies showed that the level of disclosure in this area is low (less than $50 \%$ of the total score). However, in recent years there has been improvement since investors would want companies to disclose their business risks so that an informed decision could be made. This study shows that majority of the selected companies scored more than $50 \%$ of the total score (40 points). Nevertheless, there is still a lack of disclosure in areas such as types of contingency planning, internal auditor's findings and review of internal control systems.

\section{Disclosure of Accountability and Transparency}

This attribute is central to corporate governance issues and have been dealt extensively by the Malaysian Code of Corporate Governance through three basic principles and at least by six best practices items (MICG, 2004). This attribute looks into the disclosure of information that is pertinent to investors' decision making as well as stakeholders' interests. The measurement criteria are further reflected in Table 7.

Table 7: Disclosure of Accountability and Transparency
No. Measurement Criteria
1. Disclosure of external auditor's recommendation
Calendar of activities
Disclosure of notes on non-audit fees
5. Disclosure of interim reviews
6. Disclosure of industry norm
7. Financial forecasts
8. Disclosure of regulatory requirements
9. Appointment of professional advisor
10. Disclosure of key financial ratios
11. Segmental reporting
12. Directors' remunerations
13. Disclosure of risk assessment

Score

Score

M n mum: 31/85

Max mum: 60/85

Mean: 41.99

Med an:43

Standard dev at on: 7.26 
Figure 7: Disclosure of Accountability and Transparency

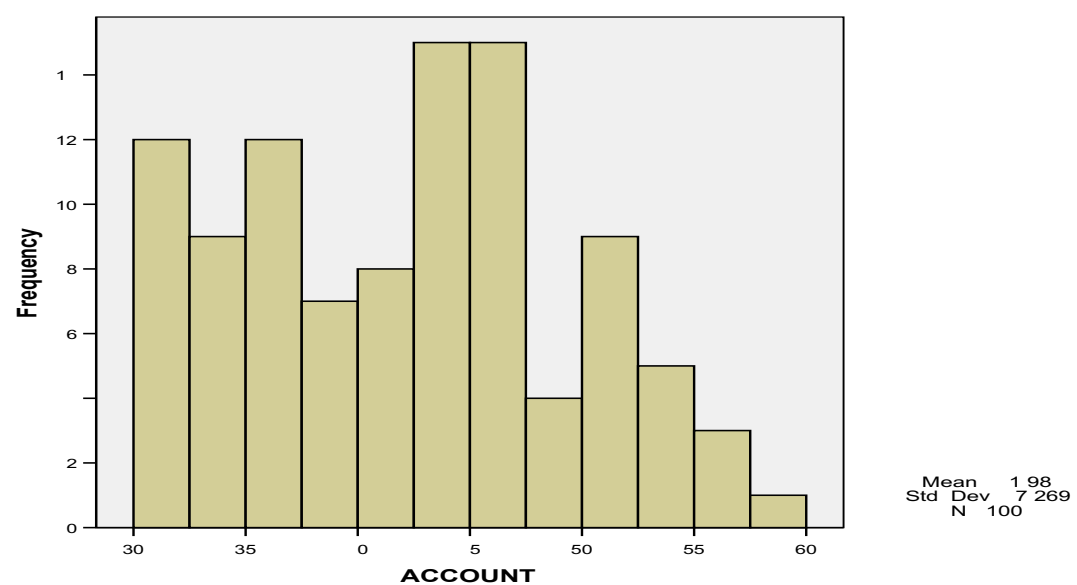

Based on the results, it was noted that most companies on average surpassed the minimum requirements of disclosing this attribute. Majority of the companies tend to disclose the information as per regulatory requirement such as accounting policies adopted and key financial ratios, segmental report and director's remuneration. It was noted that most companies disclosed the salary band of directors rather than which director was paid what amount. In the case where non-audit fees were incurred, there was not much explanation on it except for "paid for consultancy service". There was also lack of disclosure of industry norms and financial forecasts. It could be that management would not want to be tied to the forecast, as there will be a lot of explanation when the forecasts are not met. Overall, there is still room of improvement in this area and it will be more effective if companies are more transparent and accountable in their business dealings.

\section{Disclosure of Ownership Structure and Concentration}

The code specifies explicit requirements under this heading, 5 out of the 13 basic principles and 13 of the 33 Best Practices proposed by the Code deal on the issues of board balance and balanced ownership (MICG, 2004).

This attribute measures the level of disclosure of directors' and management shareholdings and minority shareholder's participation. The measurement criteria are as in Table 8.

Table 8: Disclosure of Ownership Structure and Concentration
No. Measurement Criteria
1. Disclosure of information on major shareholders
2. Disclosure of shareholdings of the directors and management
3. Disclosure of minority shareholders' rights and participation
4. Disclosure of information on nominees shareholdings
5. Disclosure of share classifications

Score

M n mum: $17 / 35$

Max mum: $33 / 35$

Mean: 21.46

Med an:21

Standard dev at on: 3.58 
Figure 8: Disclosure of Ownership Structure and Concentration

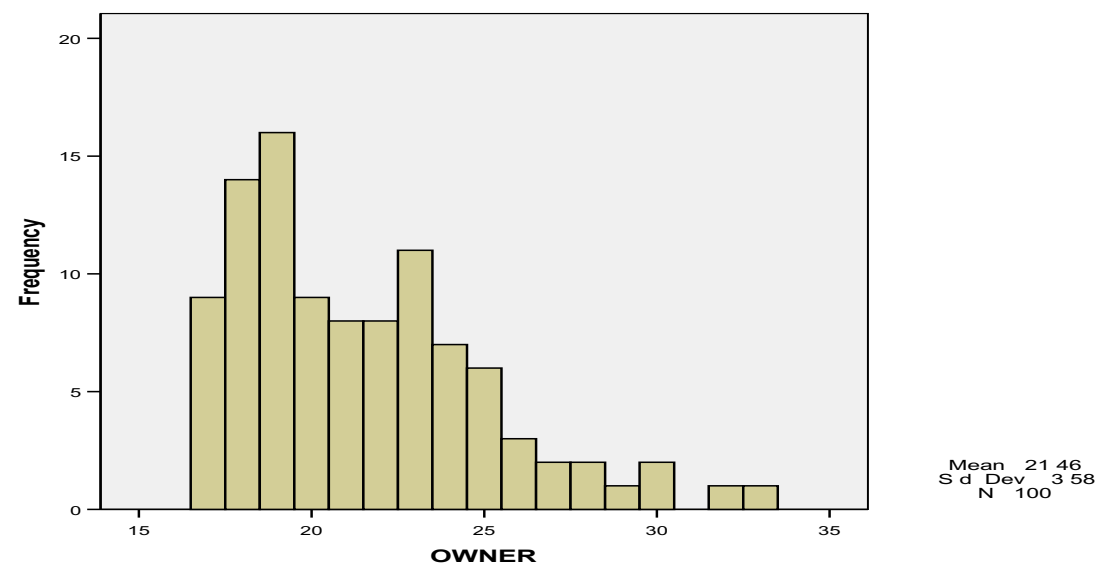

The analysis showed that there is a high level of disclosure in this area. The reason could be that companies are required to disclose their largest 30 shareholders and their proportion of shareholdings. Hence, the high level of compliance of corporate governance practices. Not many companies disclosed information on nominee shareholdings as well as minority shareholders' rights and participation.

\section{Disclosure of Information to Shareholders and Investors Relations Functions}

This attribute measures the disclosure of information of shareholders' approval of company's activities, communication platform between board and investors as well as the accessibility to company's information. The measurement criteria are listed in Table 9.

Table 9: Disclosure of Information to Shareholders and Investor Relations Functions

No. Measurement Criteria

1. Disclosure of shareholders' approval for major activities, plans and

2. Communication platform between the companies and their

3. Disclosure of shareholders' proxies

4. Accessibility to companies information

5. Disclosure of dividend policies

\begin{tabular}{|l|}
\hline Score \\
\hline Minimum: $18 / 40$ \\
\hline Maximum: $36 / 40$ \\
\hline Mean: 25.00 \\
\hline Median:21 \\
\hline Standard deviation: 3.58 \\
\hline
\end{tabular}


Figure 9: Disclosure of Information to Shareholders and Investor Relations Functions

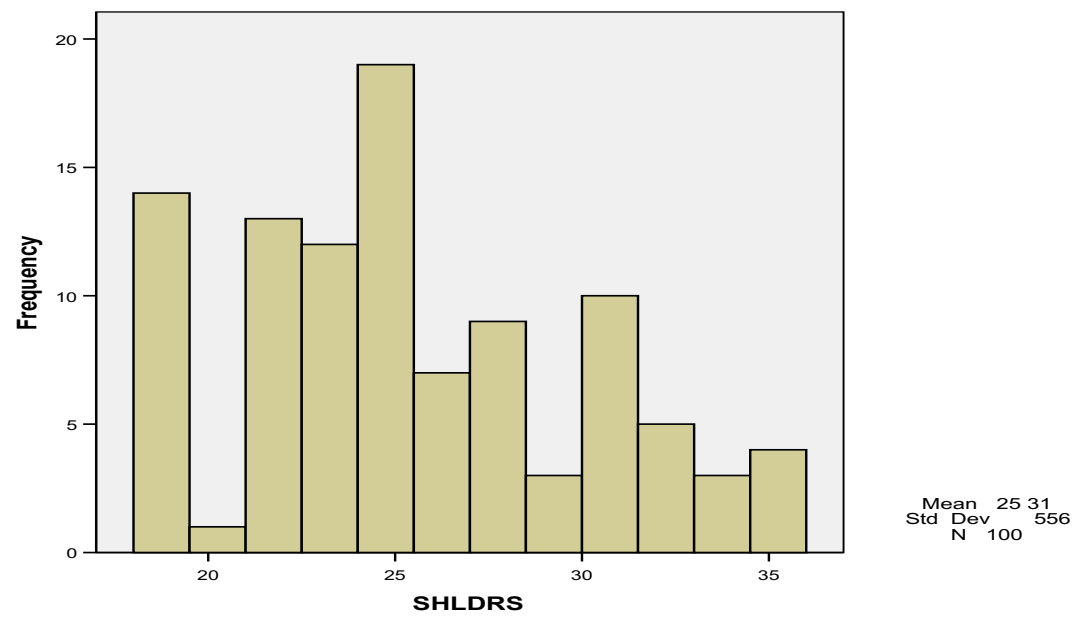

Based on the figures above, there is a considerable level of disclosures made on shareholder's information and investor relations. Most of the companies scored more than $50 \%$ of the assigned total score (40). The reason could be many companies recognized the importance of information need to flow freely and in timely manner so that investors' could make an informed investment decision. Furthermore, most companies realized that to attract foreign institutional investors' participation, high disclosure of information in this area is crucial. Most of the companies have a corporate websites and quite a number of them have a dedicated section on investor relations. Information on company's performance and how to contact them are disclosed in that section. Nevertheless, there seems to be a lack of information on minority shareholders rights and participation in the annual report. This area could be further improved so that a proper check and balance could be placed in the company.

\section{Business Ethics and Board Responsibility}

Ideally, a well governed company should have a code of business ethics and conduct which is intended to inform all of its employees of their legal and ethical obligations to the shareholders and stakeholders as well as to promote honest and ethical conduct among the board and employees of the organization. This attributes examines the disclosure of ethical nature of the management and employees as well as the quality related activities of the company. The measurement criteria are listed in Table 10.

Table 10: Disclosure of Business Ethics and Board Responsibility
No. Measurement Criteria
1. Disclosure of company code of conduct and business ethics
2. Disclosure of complaints procedures
3. Disclosure of the fiduciary duties of the BOD, management and employees
4. Disclosure of any reprimand issued to the company
5. Plans for employees' suggestions
6. Disclosure of disciplinary matters
7. Value added statement
8. Quality related policies

Score

M n mum: 8/30

Max mum: 19/30

Mean: 11.45

Med an:11

Standard dev at on: 2.57 
Figure 10: Disclosure of Business Ethics and Board Responsibility

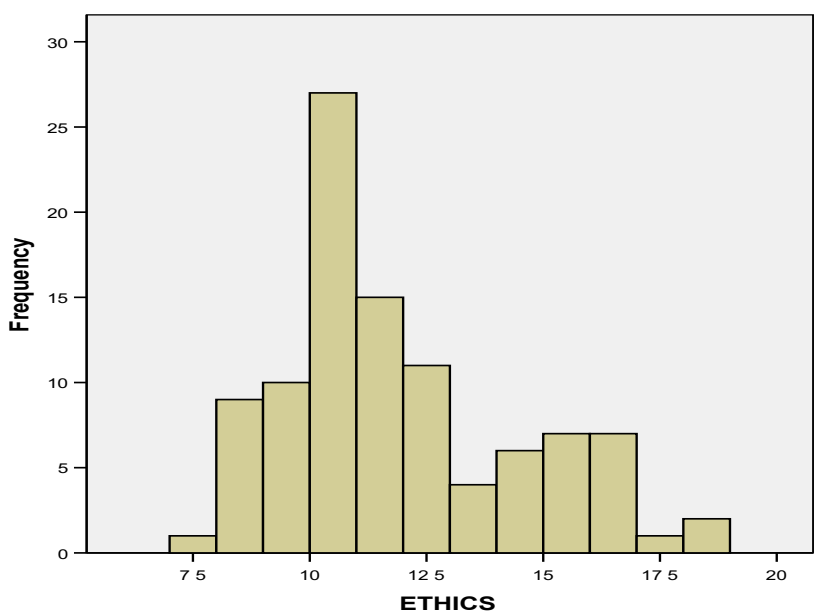

$\stackrel{\text { Mean }}{\text { Std }} \underset{\mathrm{Dev}}{11} 2572$

Based on the above, it can be concluded that there is a low level of disclosure in this area. Most companies only reported the existence of the code of business ethics in their organization but did not provide much information on how the code is practiced and upheld. As far as disclosure of quality information, many companies, especially Maybank, IJM, Genting, Tanjong Plc and Public Bank, just disclosed the quality awards that they have received from various notable organizations.

\section{Intellectual capital}

Human capital plays an important role in corporate governance practice (Castanias and Helfat, 2001) and the board must recognize that this capital needs to be protected and upgraded just as tangible assets are. Therefore, it is appropriate to examine the disclosure level of this attribute in order to determine how the companies govern this intangible asset. The measurement criteria for this attribute are specified in Table 11.

Table 11: Disclosure of Intellectual Capital Management

No. Measurement Criteria

1. Disclosure of company's training policies

2. Disclosure of knowledge management system

3. Disclosure of staff welfare

4. Disclosure of medical benefits and scholarship

5. Promotion policies

6. Disclosure of health and safety measure

7. Efforts in enhancing intellectual capital efficiency

\section{Score}

M n mum: $7 / 30$

Max mum: 15/30

Mean: 9.23

Med an:9

Standard dev at on: 1.43 
Figure 11: Disclosure of Intellectual Capital Management

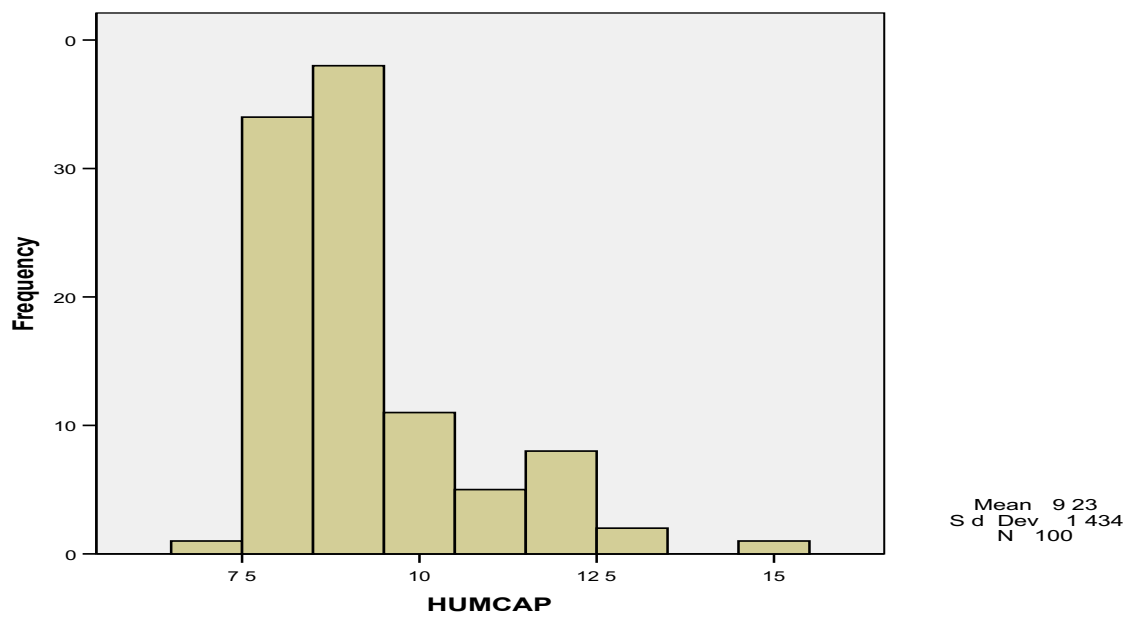

From the above, it can be concluded that most companies did not place importance in disclosing management of human capital. This is evident in the low score in this area. A majority of the companies reported their training policies to enhance employees' capabilities and skills as well as health and safety measures. Knowledge management system was not evident in the reporting as well as efforts in enhancing intellectual capital efficiency.

\section{Summary of Analysis}

In brief, the analysis has revealed that most companies tend to disclose information that is required by the Code or the Listing Requirements of Bursa Malaysia. This could be seen in the high scores obtained in the area of mandatory disclosure. This is evident where the attributes such as disclosure of board, committee and management, risk management and internal control, accountability and transparency, ownership structure and concentration and information to shareholders have $50 \%$ or higher in the raw score. Thus it can be said that most companies are not willing to disclose more than what is legally necessary.

\section{Corporate governance and financial performance}

In order to answer the question, "Is there a relationship between corporate governance practice and firm's performance", statistical test in the form of Pearson's correlation analysis was performed.

A correlation analysis was performed to determine the relationship between the total raw score of corporate governance practices and firm's performance (return on equity), and stock prices performance. The result is presented in Tables 12 and 13 respectively.

Table 12: Correlation analysis between Total Raw Score and Stock Prices Performance

\begin{tabular}{|ll|l|l|}
\hline & & RAWSCORE & SP \\
\hline RAWSCORE & Pearson Correlation & 1 & -.151 \\
& Sig. (2-tailed) & & .133 \\
& $\mathrm{~N}$ & 100 & 100 \\
$\mathrm{SP}$ & Pearson Correlation & -.151 & 1 \\
& Sig. (2-tailed) & .133 & \\
& $\mathrm{~N}$ & 100 & 100 \\
\hline
\end{tabular}

The result shows that there is minimal or nearly inexistence negative relationship between corporate governance practices and firm's performance (stock prices). The relationship is also insignificant (pvalue: $133>.05$ ). This could be due to the fact that market is always efficient; hence all information has been fully absorbed by the stock prices. Thus, high level of corporate governance practices has little impact on share prices. 
This finding is in concurrence with Bernard and Thomas (1990) that stated investors do not fully exploit the information in current earnings to infer future earnings changes. Thomson and Chu (2002) supports the findings that a negative correlation between firm's performance and corporate governance implies that badly governed companies report less conservative earnings. Furthermore, there are a lot of other factors such as economic, political and market that influence stock performance.

Realising that stock price performance is a weak financial performance indicator, this study employs return on equity as the dependent variable to test the relationship with corporate governance practices. The result is shown below:

Table 13: Correlation between Total CG Score and Return on Equity

\begin{tabular}{|ll|l|l|}
\hline & & RAWSCOR & ROE \\
\hline RAWSCOR & Pearson & 1 & .162 \\
& Correlation & & .108 \\
& Sig. (2-tailed) & & 100 \\
ROE & $\mathrm{N}$ & 100 & 1 \\
& Pearson & .162 & \\
& Correlation & .108 & \\
& Sig. (2-tailed) & & 100 \\
& $\mathrm{~N}$ & 100 & 1 \\
\hline
\end{tabular}

The result shows that there is a positive relationship between corporate governance practices and firm's performance (return on equity). The relationship has low significance ( $p$ value.162 >.05). This shows that high level of corporate governance practices has little impact on firm's performance (return on equity).

A correlation analysis was also performed on the total weighted corporate governance score (TWCGS) and ROE in Table 14.

Table 14: Correlations between TWCGS and Return on Equity

\begin{tabular}{|ll|l|l|}
\hline & & ROE & TWCGS \\
\hline ROE & Pearson & 1 & $.219\left(^{*}\right)$ \\
& Correlation & & .029 \\
& Sig. (2-tailed) & & 100 \\
& $\mathrm{~N}$ & 100 & 1 \\
TWCGS & Pearson & $.219\left(^{*}\right)$ & 1 \\
& Correlation & .029 & \\
& Sig. (2-tailed) & 100 & 100 \\
\hline
\end{tabular}

* Correlation is significant at the 0.05 level (2-tailed).

The result shows that there is a positive and significant relationship ( $\mathrm{p}$ value- $0.029<0.05$ ) between return on equity and total weighted corporate governance score (TWCGS). The reason could be that high weighting on the disclosure on the following attributes has given a positive impact on the financial performance (ROE). 
Table 15 : Impact on the following attributes on the analysis

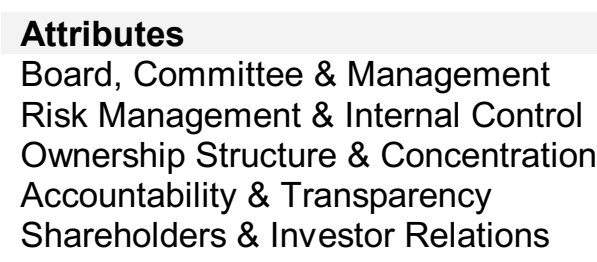

Attributes

Board, Comm

Ownership Structure \& Concentration

Shareholders \& Investor Relations

\author{
Weighting \\ 15 \\ 15 \\ 15 \\ 20 \\ 15
}

The above results for total raw score and weighted score are consistent with Deutsche Bank's research which also showed that there was a positive relationship between the historic governance assessment of the companies and their profitability (ROE) (Deutche Bank, 2005).

\section{Conclusions}

This study aimed to investigate the relationship between corporate governance practices (as indicated by corporate governance disclosures) and company's financial performance. Certain corporate structures and practices were examined to determine if they have any effect on company's performance. The corporate governance practices were assessed based on the level of disclosure made in the companies' annual reports. For financial performance, stock price performance and return on equity (ROE) were used as the proxies. The results show a similar pattern emerging in terms of corporate governance disclosure. This could be that majority of the companies have developed an acceptable level of corporate governance disclosure. It also indicates that perhaps most companies have a common format in terms of reporting their corporate governance practices.

The correlation between corporate governance practice and firm's performance as measured by stock prices showed that there is an insignificant negative correlation between the two variables. However, the correlation between corporate governance practice and firm's performance as measured by return on equity showed that there is significant positive correlation between the two variables.

There are two major limitations in this study. The application of the corporate governance index and the assessment of corporate governance ratings are very subjective and open to individual bias. Furthermore, the corporate governance ratings are based on the relevant information in the annual reports, hence the assessment of the corporate governance practices based on what is disclosed. The usage of performance indicators such as financial indicators or return on equity may not be appropriate. Moreover, the study covers only a period of one year on a relatively small sample (100 companies). This may lead to different results if the sample increases or the study period is extended. Furthermore, the sample is selected from big cap companies which are the index components, thus they are expected to practice higher governance standards. In addition, these companies could afford to obtain best advice and services from investment professionals and accountants during the corporate reporting period.

Based on the limitations outlined above, this research could be further enhanced by looking into diversifying the sample selection by including small and medium cap companies. In addition to reviewing the disclosure made in the annual report, future research should include interviews with the top management, board members, relevant regulators and investors to get a more holistic view.

\section{References}

Bauer, R., Gunster, N. and Otten, R., (2004) 'Empirical Evidence on Corporate Governance in Europe: The Effect on Stock Returns, Firm Value and Performance', Journal of Asset Management, Vol. 5, No. 2, pp. 91-94.

Bernard, V.L. and Thomas, J (1990) 'Evidence that stock prices do not fully reflect the implications of current earnings for future earnings', Journal of Accounting and Economics, Vol. 13, No. 4, pp. 305-340. 
Bhagat, S. and Black, B. (2002) 'Board independence and long-term performance', Journal of Corporation Law, Vol. 27, pp. 231-273.

Brown, L. and Caylor, M. (2004) 'The Correlation between Corporate Governance and Company Performance, Research Study Commissioned by the Institutional Shareholder Services.

Byrd, J.W. and Hickman, K.A. (1992) 'Do outside directors monitor managers? Evidence from tender offer bids', Journal of Financial Economics, Vol. 32, pp.195-222.

Carcello, J.V. and Neal, T.L. (1999) 'Audit committee characteristics and auditor reporting', Working Paper, The University of Tennessee.

Castanias, R.P. and Helfat, C.E. (2001) 'The managerial rents model: Theory and empirical analysis', Journal of Management, Vol. 27, No. 6, pp. 661.

Demsetz, H. and Lehn, K. (1985) 'The structure of corporate ownership: causes and consequences', Journal of Political Economy, Vol. 93, No. 6, pp.1155-1177.

Denis, D.J. and Sarin, A. (1997) 'Ownership and board structures in publicly traded corporations', The Journal of Finance, Vol 52, No. 1, pp. 135-160.

Deutsche Bank Research. (2005), Current Issues, February, Vol. 9.

Donaldson, L. and Davis, J. (1991) 'Stewardship theory or agency theory: CEO governance and shareholder returns', Australian Journal of Management, Vol. 16, No. 1, pp.49-64.

Drobetz, W. and Schillhofer, A. and Zimmermann, H. (2004) 'Corporate Governance and Expected Stock Returns: Evidence from Germany’ European Financial Management, Vol. 10, No. 2, pp. 267-293.

Gompers, P.A. and Lerner, J. (2003) 'The really long-run performance of initial public offerings: The pre-Nasdaq evidence' Journal of Finance, Vol. 58, No. 4.

Healy, P.M. and Palepu, K.G (2001) 'Information asymmetry, corporate disclosure, and the capital markets: A review of the empirical disclosure literature, Journal of Accounting and Economics, Vol. 31, No. 1-3, pp. 405-440.

Hermalin, B.E. and Weisbach, M.S (1991) 'The Effects of Board Composition and Direct Incentives on Firm Performance, Financial Management, Vol. 20, No. 4, pp. 101-112.

Holderness, C.G. and Kroszner, R.S. and Sheehan, D.P (19991) 'Were the Good Old Days That Good? Changes in Managerial Stock Ownership Since the Great Depression, The Journal of Finance, Vol. 54, No. 2, pp. 435-469.

Keasey, K. and Thompson, S. and Wright, M. (1999) Corporate governance, Edward Elgar Pub.

McConnell, J.J. and Servaes, H. (1990) 'Additional evidence on equity ownership and corporate value', Journal of Financial Economics, Vol. 27, No. 2, pp.595-613.

McConnell, J.J. and Servaes, H. (1995) 'Equity ownership and the two faces of debt', Journal of Financial Economics, Vol. 39, pp.131-157.

Mcmullen, D.A. and Raghunandan, K. (1996) 'Enhancing Audit Committee Effectiveness', Journal of Accountancy, Vol. 182, No. 2, pp. 79-82.

Morck, R., Shleifer, A. and Vishny, R.W. (1988) 'Management ownership and market valuation: an empirical analysis', Journal of Financial Economics, Vol. 20, pp.293-315.

Perry, T. and Shivdasani, A.(2005) 'Do Boards Affect Performance? Evidence from Corporate Restructuring, Journal of Business, Vol. 78, No. 4, pp. 1403-1432.

Pincus, K., Rusbarsky, M. and Wong, J. (1989) 'Voluntary formation of audit committees among NASDAQ firms', Journal of Accounting and Public Policy, Vol. 8, pp.239-265.

Rechner, P.L. and Dalton, D.R. (1989) 'The impact of CEO as board chairperson on corporate performance: evidence vs. rhetoric', Academy of Management Executive, Vol. 3, No. 2, pp.141143.

Rechner, P.L. and Dalton, D.R. (1991) 'CEO duality and organizational performance: a longitudinal analysis', Strategic Management Journal, Vol. 12, pp.155-160.

Rosenstein, S. and Wyatt, J.G. (1990) 'Outside directors, board independence and shareholder wealth', Journal of Financial Economics, Vol. 26, pp.175-191.

Stulz, R. (1988) 'Managerial discretion and optimal financing policies' Journal of Financial Economics, Vol. 26, No. 1, pp. 3-27. 